\title{
The Role of Net Development as a Barrier to Moisture Loss in Netted Melon Fruit (Cucumis melo L.)
}

\author{
Thanidchaya Puthmee \\ The United Graduate School of Agricultural Sciences, Iwate University, \\ Tsuruoka, 997-8555 Japan
}

Kenji Takahashi, Midori Sugawara, Rieko Kawamata, Yoshie Motomura, and Takashi Nishizawa ${ }^{1}$

Faculty of Agriculture, Yamagata University, Tsuruoka, 997-8555 Japan

Toshiyuki Aikawa

Kanto-nosan Co., Ltd., Nasu-town, Tochigi, 325-0001 Japan

\author{
Wilawan Kumpoun \\ Science and Technology Research Institute, Chiang Mai University, \\ Chiang Mai 50200 Thailand
}

Additional index words. ethylene, fissure, peroxidase, suberin, transpiration rate

\begin{abstract}
The transpiration rate of cuticular membrane and fissures that comprise the netting on fruits of three netted melon cultivars, Life, Andesu, and Gurandoru, were measured during fruit development. Fissures in the equatorial region first developed vertically, then became interconnected by horizontal fissures as the fruit developed. Some cracks remained along the net, even at the fruit ripening stage, regardless of cultivar. Both lignified and suberized cell wall layers in the net tissues of the cultivar Life were thinner than those of the other cultivars, probably because of the shorter developmental period of fruits in the variety. Nevertheless, net transpiration rate did not differ significantly among cultivars at the fruit ripening stage. Peroxidase (POD) activity in the skin tissues of 'Life' was lower than that in 'Andesu' and 'Gurandoru' throughout fruit development and was not correlated with climacteric ethylene production. Among these cultivars, significantly higher ethylene production occurred in 'Life' fruit at the ripening stage. This can accelerate membrane permeability of hypodermal tissues, resulting in rapid fruit softening. Our results indicate that the net tissues of netted melons can be as waterproof as cutinized membranes if suberized cell wall layers with wax depositions develop below the net fissures at the fruit ripening stage.
\end{abstract}

Fruit firmness is determined not only by the changes in cell wall structures (DosSantos et al., 2011; Rose et al., 1998) but also by the waterproofing ability, which is mainly regulated by the turgor pressure of hypodermal tissues (Saladié et al., 2007) and structure of the cuticle (Chaïb et al., 2007; Lester, 1988; Matas et al., 2009; Saladié et al., 2007). Recently, fruit firmness-associated QTLs have been identified in chromosomes for assessing the genetic control of texturerelated traits (Causse et al., 2002; Chaïb et al., 2007; Chapman et al., 2012).

Fruit surfaces are generally covered with the lipophilic substance referred to as a "cutin," which impedes the loss of water from hypodermal tissues. Nevertheless, water in the hypodermal tissues is gradually lost during storage because of cuticular transpiration that

Received for publication 20 June 2013. Accepted for publication 25 Sept. 2013.

This study was supported by JSPS KAKENHI Grant Number 22580026.

${ }^{1}$ To whom reprint requests should be addressed; e-mail nisizawa@tds1.tr.yamagata-u.ac.jp. compromises the fruit's antidesiccation mechanism (Riederer and Schreiber, 2001).

In netted melon fruit, however, fissures develop in the rind during early fruit development and increase in length and width as the fruit grows (Keren-Keiserman et al., 2004a; Webster and Craig, 1976). Initially, fissures develop vertically in the equatorial region of netted melon fruit. Fissures then develop horizontally to interconnect the vertical fissures as the fruit continues to mature (Suzuki and Nonaka, 2004). Periderm tissues with waxy suberized cell wall layers heal these fissures or naturally occurring wounds. The network pattern formed by these healed fissures is referred to as a "net" (KerenKeiserman et al., 2004a; Lester, 1988; Webster and Craig, 1976). This desiccated network pattern is usually complete by fruit ripening, and both the depth and width of the vertically developed elements of the net become indistinguishable from those of the horizontally developed elements.

Although the net also has waterproofing ability, water loss in netted melon fruit is often much greater than that in non-netted melon fruit, suggesting that the net might be more water-permeable than cuticular membranes (Lester, 1988). However, changes in the transpiration rate of cuticular membranes and net during fruit development have not yet been measured separately.

The waterproofing ability of periderm tissue depends not only on its chemical components, but also on its anatomical structures (Schreiber et al., 2005). In fact, unhealed cracks can still be observed along the netted surface, even at fruit ripening, suggesting that moisture from the hypodermal tissues could be lost through these compromised phellem tissues (Lester, 1988; Lester and Bruton, 1986).

Suberization of artificially wounded tissues in netted melon fruit is often associated with POD activity, which can polymerize phenolic monomers to generate a matrix of suberin polymer (Keren-Keiserman et al., $2004 b$ ). Ethylene is thought to be involved in the development of lignified cell walls containing suberin polymers (Gerchikov et al., 2008) through the activation of POD activity (Argandoña et al., 2001).

The netted melon cultivar Life belonging to the Reticulatus group is one of the oldest netted melon cultivars in Japan, and is preferred by consumers because of its sweet fragrance and yellow skin (Nishizawa et al., 2009). 'Life' also has some physiologically specific characteristics, i.e., faster fruit growth, high climacteric ethylene production, development of an abscission layer at the peduncle, and rapid fruit softening during storage, resulting in its short shelf life (Nishizawa et al., 2009). In addition, its horizontally developed net elements are often narrower than those that vertically develop, probably because of its shorter fruit developmental period. This suggests that the short shelf life of 'Life' fruit results from a higher transpiration rate from the fruit surface associated with incomplete net development, rather than high membrane permeability in the hypodermal tissues.

Here, changes in the transpiration rate from the cuticle and net of 'Life' fruits were measured separately. These results were then compared with same measurements of fruits of the cultivars Andesu and Gurandoru, which also belong to the Reticulatus group but show a different skin texture and fruit ripening, to clarify the role of net development as a barrier to moisture loss. These two cultivars also show climacteric ethylene evolution at the ripening stage, but the fruit of 'Andesu' retains its green skin color and does not develop an abscission layer (Nishizawa et al., 2000). The fruit of 'Gurandoru' also does not develop an abscission layer but the skin shows a distinctively glossy color and becomes yellow at the ripening stage (Seko, 2004). In addition, both cultivars have longer fruit developmental periods and a longer shelf life than 'Life'.

\section{Materials and Methods}

Plant materials and fruit development. On 5 April, 2011, seeds of three netted melon cultivars, Life, Andesu, and Gurandoru were 
sown in 0.3-L plastic pots in a glasshouse at Yamagata Sand Dune Experimental Station (Sakata, Japan). The field soil was amended with slow-release $80 \mathrm{~N}-160 \mathrm{P}-160 \mathrm{~K}$ fertilizer at $\mathrm{kg} \cdot \mathrm{ha}^{-1}$, lime at $70 \mathrm{~kg} \cdot \mathrm{ha}^{-1}$, and compost at $800 \mathrm{~kg} \cdot \mathrm{ha}^{-1}$ before transplanting the plants.

On 26 April, 15 seedlings per cultivar with two unfolded leaves were transplanted into the field at the experimental station at a spacing of $2.7 \mathrm{~m} \times 0.8 \mathrm{~m}$. Female flowers were pollinated by bees and allowed to bear four fruits per plant, as described previously (Nishizawa et al., 2000). Five fruits per cultivar were harvested according to the following differences in net development: no fissure development (stage I), development of vertical shallow fissures in the equatorial region of the fruit rind (stage II), development of horizontal fissures and interconnection with vertical fissures associated with the development of healing periderm tissues (stage III), development of subtle meshwork of periderm tissues on whole fruit surface (stage IV), and completion of the desiccated net associated with the ripening stage of the fruit (stage V).

Transpiration rate of cuticle and net. The transpiration rates of the cuticle and net were measured in a chamber kept at $14{ }^{\circ} \mathrm{C}$ and $63 \%$ relative humidity $(\mathrm{RH})$. The cut surface of the peduncle was covered by a harmless silicone caulk (Dow Corning 3140 RTV, MI) immediately after fruit harvest to prevent moisture loss from the peduncle (Beaudry et al., 1987). Two to four polypropylene (PP) cylinders (3 and $4 \mathrm{~cm}$ in diameter and height, respectively) were then affixed to the fruit along the equatorial region using the same caulk. Each of these cylinders was connected to a $50-\mathrm{mL}$ PP bottle filled with calcium chloride using a polyvinyl chloride (PVC) tube. All cylinders were then purged with nitrogen gas $(0.2$ $\mathrm{mL} \cdot \mathrm{min}^{-1}$ ) for $30 \mathrm{~min}$ to exclude moisture. Subsequently, compressed air $(\mathrm{RH}<10 \%)$, desiccated using $13 \mathrm{~L}$ silica gel in a PVC cylinder $(12 \times 107 \mathrm{~cm}$ in diameter and length, respectively), was supplied from a $7 \mathrm{~m}^{3}$ aircylinder $\left(0.2 \mathrm{~mL} \cdot \mathrm{min}^{-1}\right)$ for $3 \mathrm{~h}$. The transpiration rate per unit area of the fruit surface (combined transpiration rate of both cuticle and net) was determined as the weight gain of each $50 \mathrm{ml}$ PP bottle after the air supply. Moisture in the air was also monitored by supplying air $\left(0.2 \mathrm{~mL} \cdot \mathrm{min}^{-1}\right)$ directly to the PP bottle from the air tank.

To measure the transpiration rate from the cuticle, nets in half of the cylinders were shielded by the silicone caulk, and the transpiration rate was measured as described above. After the transpiration measurement, rind tissues were scooped out alongside the attached PP cylinder, stained by Schiff's reagent for $20 \mathrm{~min}$, and the development of net tissues was observed under a stereomicroscope (SZ-ET; Olympus, Tokyo, Japan). In addition, the net area of the rind was calculated from the scanned photos using image analyzing software (Motic Image Plus 2.1S; Shimadzu, Kyoto, Japan). The transpiration rate from the net area was calculated as the difference in transpiration rate between nonshielded and shielded nets.
In stage I, fissures were invisible to the naked eye and could not be shielded by the silicone caulk. Therefore, transpiration rate obtained in stage I was regarded as the same as that of the cuticle.

Ethylene production. To measure ethylene production, the valves of the attached cylinders were closed for $1 \mathrm{~h}$ and the ethylene concentration in headspace gas $(1.0 \mathrm{~mL})$ was measured using a gas chromatograph (GC8A; Shimadzu, Kyoto, Japan) with a flame ionization detector, as described previously (Nishizawa et al., 2002).
POD activity. Disks were taken from the equatorial region of the fruit using a cork borer with a diameter of $2 \mathrm{~cm}$, and the skin tissue ( $\approx 1 \mathrm{~mm}$ thickness) was sliced from the

Table 1. Correlation between developmental stage of fissures (nets) and fruit age (days after anthesis).

\begin{tabular}{lccccc}
\hline & \multicolumn{5}{c}{ Stage } \\
\cline { 2 - 6 } Cultivar & I & II & III & IV & V \\
\hline Life & 10 & 14 & 22 & 26 & 38 \\
Andesu & 10 & 19 & 26 & 40 & 46 \\
Gurandoru & 10 & 18 & 29 & 40 & 46 \\
\hline
\end{tabular}
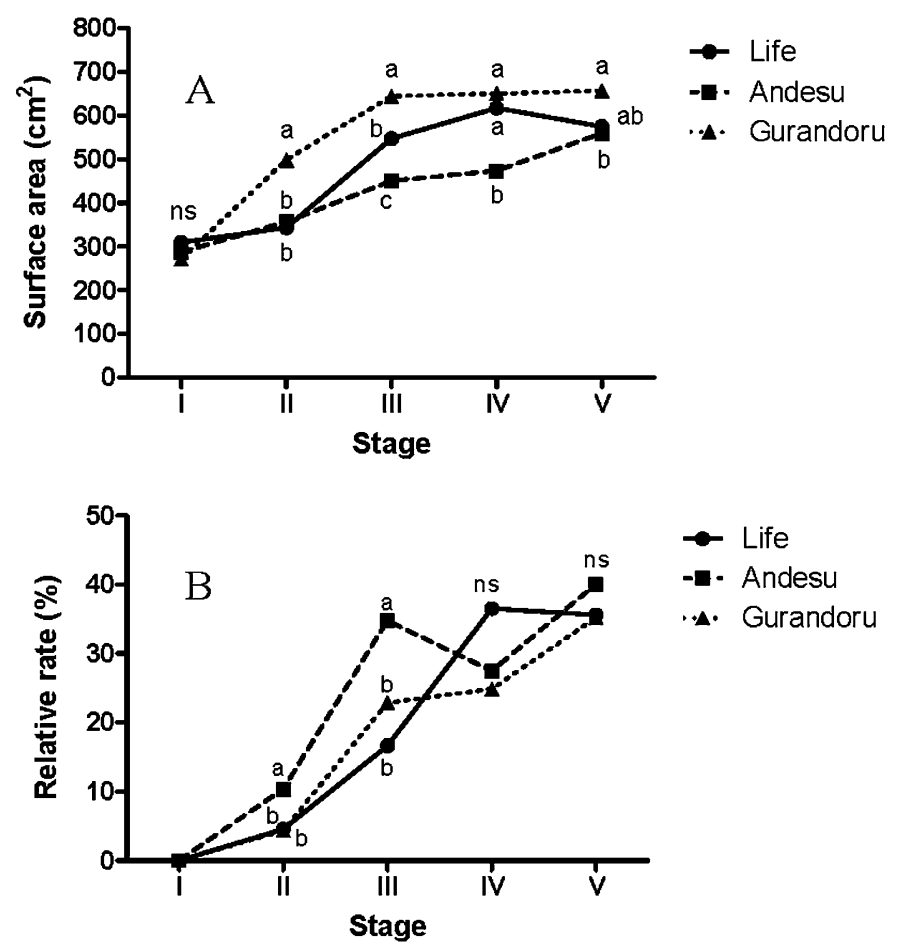

Fig. 1. (A) Changes in fruit surface area and (B) ratio of net to whole surface area (expressed as percentage) during fruit development. The data followed by the different letters are significantly different at $P \leq$ $0.05(n=5)$ by Tukey's honestly significant difference test. Ns, Nonsignificant.

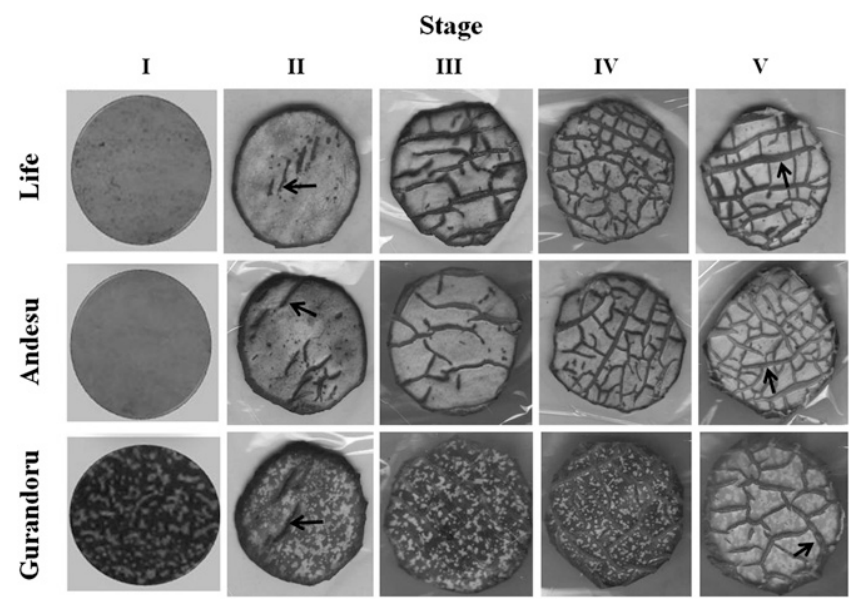

Fig. 2. Changes in net development during fruit development. Stage I: no fissure development, stage II: development of vertical fissures in the equatorial region, stage III: development of horizontal fissures in the equatorial region, stage IV: development of subtle mesh on the whole fruit surface, and stage V: completion of nets and ripening. Rind samples were stained with Schiff's reagent. Arrows show vertical fissures. 
flesh with a surgical knife. The peel $(0.5 \mathrm{~g})$ was then powdered in liquid nitrogen and incubated for $30 \mathrm{~min}$ after adding $50 \mathrm{~mm}$ sodium phosphate buffer $(10 \mathrm{~mL})$ at $\mathrm{pH} 5.8$.

The mixture was then centrifuged at $3000 g_{\mathrm{n}}$ for $12 \mathrm{~min}$ at $4{ }^{\circ} \mathrm{C}$. The supernatant was collected and used for the measurement of POD activity and protein content. All subsequent procedures were carried out at $5{ }^{\circ} \mathrm{C}$. For the POD activity measurement, the supernatant $(10 \mu \mathrm{L})$, was mixed with $34.5 \%$ $\mathrm{H}_{2} \mathrm{O}_{2}(5 \mu \mathrm{L}), 50 \mathrm{~mm}$ sodium phosphate buffer $(1 \mathrm{~mL})$ at $\mathrm{pH} 7$, guaiacol $(10 \mu \mathrm{L})$, and $50 \mathrm{~mm}$ sodium phosphate buffer $(90 \mu \mathrm{L})$ at $\mathrm{pH} 5.8$ in a cuvette. An increase in absorbance at $470 \mathrm{~nm}$ was recorded every $20 \mathrm{~s}$ for 4 min using a spectrophotometer (UVmini-1240; Shimadzu, Kyoto, Japan). Total protein content was also measured by Bradford protein assay (Bradford, 1976) using bovine serum albumin as a standard. POD activity is expressed as $\min ^{-1} \cdot \mu \mathrm{g}^{-1}$ protein.

Cross sections of net tissue. To observe the cross section of the net structure, $\approx 5-\mathrm{mm}^{3}$ samples with fissures (nets) were taken from the equatorial region of the rind, fixed in FAA (formaldehyde:acetic acid:ethanol $=1: 1: 8$ ) solution; dehydrated by immersion in a mixed-solution series of $t$-butanol, ethanol, and distilled water $(10 \%, 25 \%, 40 \%, 55 \%$, $70 \%, 85 \%$, and $100 \% t$-butanol, respectively) for $24 \mathrm{~h}$ per step; and embedded in paraffin blocks.

The paraffin blocks were sliced into $15-\mu \mathrm{m}-$ thick sections by a rotary microtome (PR-50; Yamato-koki, Saitama, Japan), and paraffin was removed using a mixed-solution series of xylene and ethanol. Half sections were then stained with $1 \%$ phloroglucinol for $2 \mathrm{~min}$ and $18 \%$ hydrochloric acid for $2 \mathrm{~min}$, respectively (McClure, 1960). Lignified cell walls were observed under an optical microscope (BX51; Olympus, Tokyo, Japan).

The matching half sections were observed under a confocal laser scanning microscope (CLSM) (LSM 700; Carl Zeiss Japan, Tokyo, Japan) without staining to detect autofluorescence of suberized cell walls, as described previously (Gerchikov et al., 2008).

Surface structure analysis by SEM. Stage $\mathrm{V}$ cubic samples dehydrated by $t$-butanol were lyophilized at $5{ }^{\circ} \mathrm{C}$ using a lyophilizer (JFD-310, JEOL, Tokyo, Japan) for 4-6 h, then coated with platinum ions (JFC-1200; JEOL, Tokyo, Japan). The surface structure of the net was observed under a scanning electron microscope (SEM) (TM-3000; Hitachi High-Tech, Tokyo, Japan). Skin tissues were enzymatically isolated from the rind by a modified method of KerenKeiserman et al. (2004a). Fruit from each stage was cut into small pieces and the flesh tissues were roughly removed using a knife. The remaining rind tissues were incubated in a solution of $50 \mathrm{~mm}$ acetate buffer at $\mathrm{pH} 4$ containing $10 \mathrm{U}$ of pectinase (pectinase SS; Yakult, Tokyo, Japan) at $40{ }^{\circ} \mathrm{C}$ for $24 \mathrm{~h}$. The resulting skin tissues were washed with water to remove the remaining flesh, and were reincubated in the enzymatic solution for an
Isolation of skin tissues from fruit rind. additional $24 \mathrm{~h}$. The skin tissues were then washed again in water and dried at $40{ }^{\circ} \mathrm{C}$ in an oven.

Lipid content in the net tissues. Nets in the dried skin tissues sampled during netting stages (stage III to V) were separated from the cuticle using a surgical knife and powdered in a mill. A 1-g sample of powdered net tissue was then extracted with diethyl ether $(150 \mathrm{~mL})$ at $65{ }^{\circ} \mathrm{C}$ for $5 \mathrm{~h}$ in a Soxhlet extractor. The extract was then evaporated under continuous $\mathrm{N}_{2}$ gas flow $\left(\mathrm{mL} \cdot \mathrm{min}^{-1}\right)$ at $50{ }^{\circ} \mathrm{C}$. The weight gain of the flask after extraction was regarded as the lipid content of the net sample (AOAC, 2000).

Membrane permeability. The membrane permeability of exocarp and mesocarp was determined by electrolyte leakage. Disks (10 $\mathrm{mm}$ diameter and $2 \mathrm{~mm}$ thickness) were taken from exocarp and mesocarp tissues in the equatorial region of fruits using a cork borer. Ten disks were then floated on $100 \mathrm{~mL}$ deionized water with continuous stirring at $10^{\circ} \mathrm{C}$ for $30 \mathrm{~min}\left(\mathrm{E}_{0}\right)$, then incubated at $20^{\circ} \mathrm{C}$ for $3 \mathrm{~h}\left(\mathrm{E}_{3}\right)$ (Knowles and Knowles, 1989). Total electrolyte content (TE) was determined in the same solution after grinding the discs with a motor and filtering through a filter paper. $\mathrm{EC}$ values for $\mathrm{E}_{0}, \mathrm{E}_{3}$, and $\mathrm{TE}$ were measured independently, and percentage of
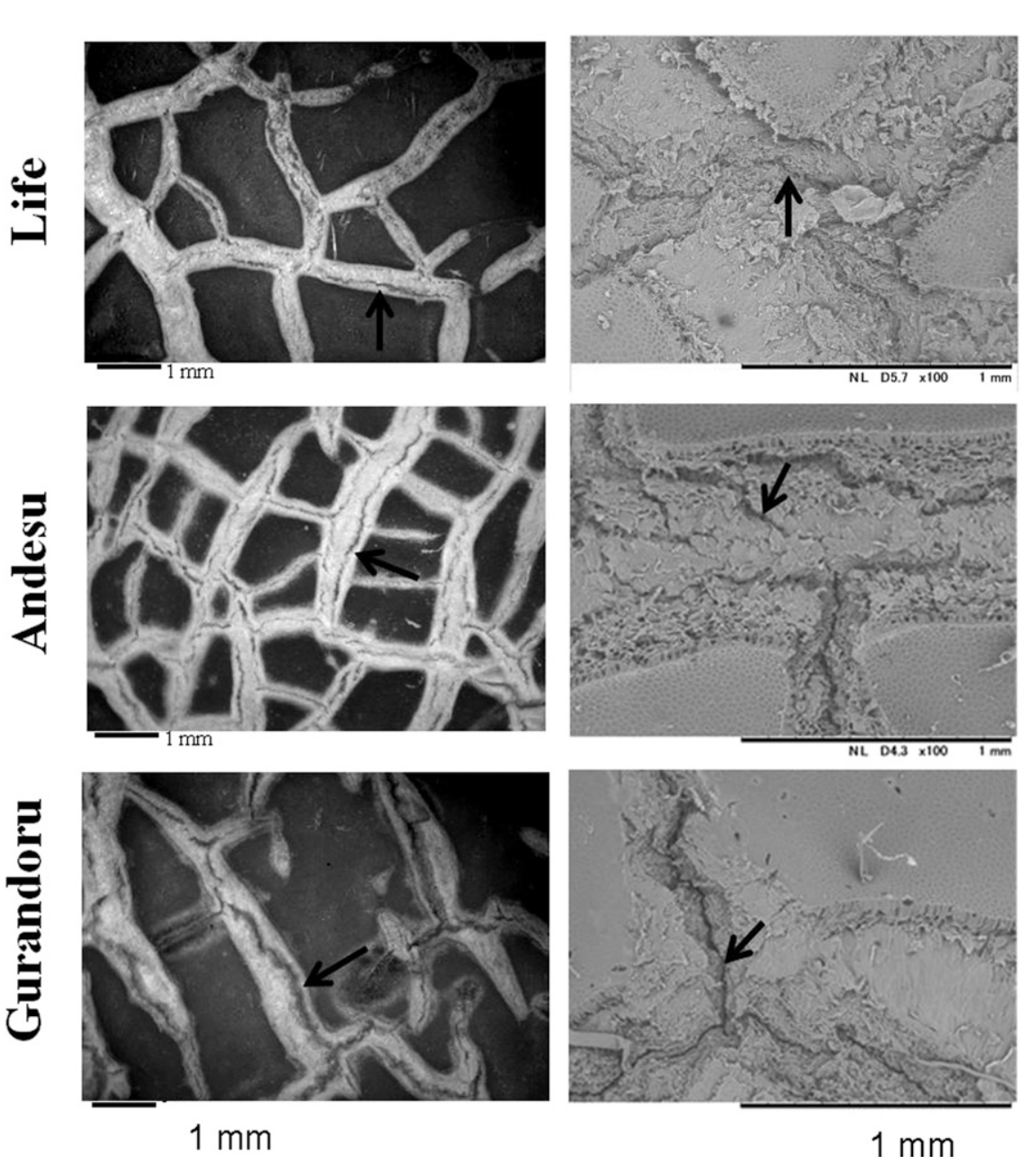

Fig. 3. Cracking in the net at fruit ripening (stage V). Stereomicroscope (left) and scanning electron microscope (right) images.

electrolyte leakage was calculated as $\left[\left(\mathrm{E}_{3}-\right.\right.$ $\left.\left.\mathrm{E}_{0}\right) / \mathrm{TE}\right] \times 100$ (Cao et al., 2008).

Statistical analysis. Data were subjected to analysis of variance, and the means among cultivars were compared with Tukey's honestly significant difference (HSD) test at $P \leq$ 0.05 using SAS for windows (version 6.12; SAS system, Cary, NC). All mean values and standard errors in the figures represent five replicates of each treatment.

\section{Results and Discussion}

Fruits of 'Andesu' and 'Gurandoru' from stage II to V were harvested at 18-19, 26-29, 40, and $46 \mathrm{~d}$ after anthesis (DAA), respectively, whereas fruits of 'Life' were harvested at $14,22,26$, and 38 DAA, respectively, indicating earlier net development and shorter developmental period of 'Life' fruit compared with the other two cultivars (Table 1) (Nishizawa et al., 2009).

Surface areas of 'Gurandoru' and 'Life' fruits increased rapidly from stage I to III and from stage II to IV, respectively, whereas that of 'Andesu' increased at a continuous rate throughout fruit development (Fig. 1A).

A rapid increase in the ratio of fissures (nets) to the whole fruit area occurred during stage II and III in 'Andesu' and 'Gurandoru',
HortScience Vol. 48(12) December 2013 
but during stage II and IV in 'Life' (Fig. 1B). Thus, net development was not necessarily linked to fruit growth rate as Combrink et al. (2001) described previously. Rather, net development depends on other factors, such as morphological characteristics of the rind and physical resistance of the cuticle to tensile force (Keren-Keiserman et al., 2004a).

Although no fissure was apparent on fruits in stage I, regardless of cultivar, the skin color of 'Gurandoru' showed a patchy pattern of white and green at stage I (Fig. 2). At stage II, small vertical fissures appeared on fruits of both 'Life' and 'Gurandoru', whereas relatively longer vertical fissures appeared in 'Andesu'. During stages III and IV, the vertical fissures increased in length and width and became interconnected by small horizontally developing fissures, regardless of cultivar. By stage $\mathrm{V}$, fissures were covered with desiccated phellem tissues and the widths of both vertical and horizontal net elements in 'Gurandoru' became similar. In 'Life' and 'Andesu', however, the horizontally developed net elements were somewhat narrower than those of vertically developed nets and this tendency was more distinct in 'Life', probably because of the shorter developmental period of its fruit (Table 1).

Histological analyses of the vertically developed net surface at stage $V$ showed that small cracks were still apparent along the nets on fruits of each of these cultivars (Fig. 3), as shown for 'Perlita' muskmelon (C. melo L. var. reticulatus) fruit previously (Lester, 1988). SEM images show these cracks more clearly; i.e., the net surface was mostly smeared with waxy substances but cracks were beginning to penetrate the phellem cell layer of fruits of each of these cultivars. This phenomenon has also been observed previously in the periderm of stored potato tubers (Serra et al., 2010).

Changes in the transpiration rate during fruit development were mainly because of changes in the transpiration rates of net but not of cuticle. The transpiration rate of the net was highest in stage II or III then decreased thereafter, whereas that of the cuticle was almost constant throughout fruit development (Fig. 4A-C). In addition, the transpiration rates of the net and the cuticle were similar in stage $\mathrm{V}\left(1-2 \mathrm{mg} \cdot \mathrm{cm}^{-2} \cdot \mathrm{h}^{-1}\right)$, in each of the cultivars studied here, which also indicates that the waterproofing ability of the periderm tissues (net) was as high as that of the cuticle.

The net transpiration rate of 'Life' fruit at stage III and IV was significantly higher than that of 'Andesu' and 'Gurandoru', suggesting an insufficient period for 'Life' fruits to complete suberization (Fig. 4B) before ripening. Nevertheless, the net transpiration rate of fruits at stage $\mathrm{V}$ did not differ significantly among cultivars, indicating the sufficiency of the net as a barrier to moisture loss, even with a shorter net development period.

Periderm tissues that develop as the result of wound healing consist of phelloderm and phellem cells that arise from the secondary meristem, phellogen (Serra et al., 2010).
Phellem tissues that develop on the abaxial side have a matrix of highly lignified and suberized polymers and work as a barrier to moisture loss (Schreiber, 2010). Optical microscope observations of vertical sections revealed that lignification of the phellem tissue occurred mainly after stage III, regardless of cultivar (Fig. 5). This was also true for suberization; i.e., suberized cell wall layers observed by CLSM were thin until stage III (Fig. 6), as also shown in 'Krimka' netted

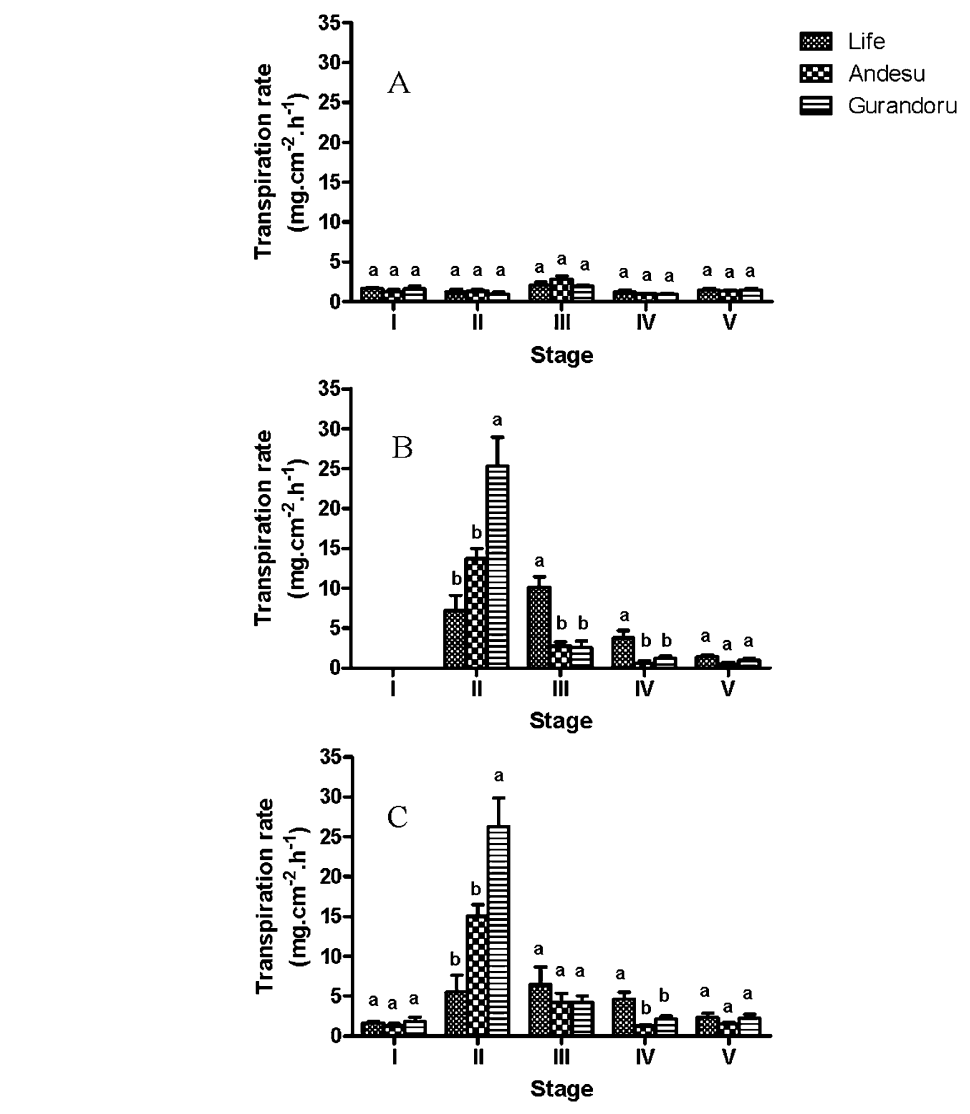

( $C$. melo $\mathrm{L}$. var. reticulatus) fruit (Gerchikov et al., 2008). By stage IV and V, both lignification and suberization take place as the periderm is raised above the fruit surface and also develops below each fissure (Fig. 6). This periderm development explains why the net is as effective as the cuticle as a barrier to moisture loss (Schreiber, 2010), regardless of the cracks that become apparent in stage $\mathrm{V}$ (Fig. 3).

Fig. 4. Changes in transpiration rate of the $(\mathbf{A})$ cuticle, $(\mathbf{B})$ the net, and $(\mathbf{C})$ the whole fruit surface during the fruit development. Different letters within columns indicate significant differences at $P \leq 0.05$ by Tukey's honestly significant difference test. Bars indicate mean $\pm \mathrm{SD}(n=5)$.

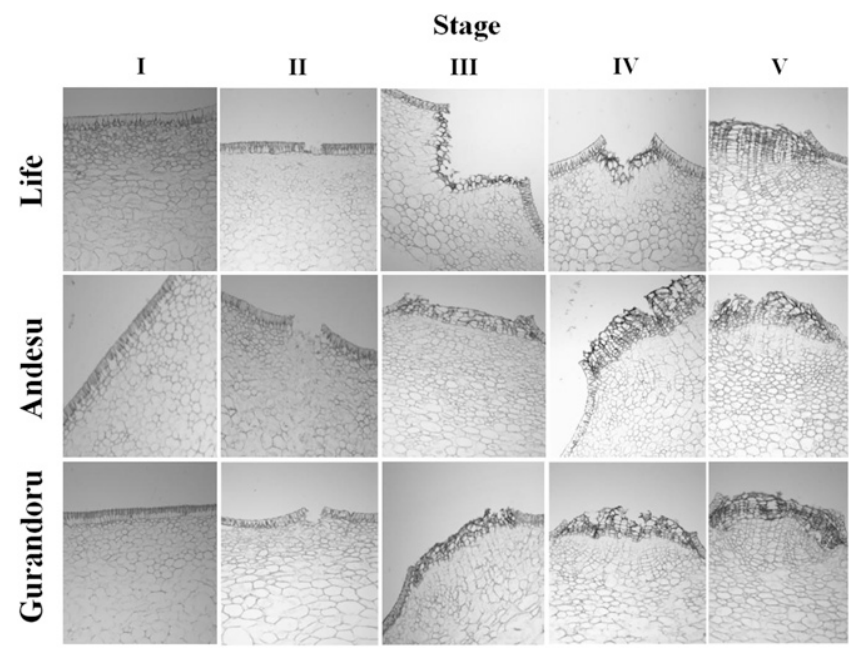

Fig. 5. Changes in the development of lignified cell walls in the cross sections of periderm tissues during fruit development. Sections were stained by phloroglucinol $/ \mathrm{HCl}$. 
The suberized cell wall layers in 'Life' at stage $\mathrm{V}$ were thinner than those of 'Andesu' and 'Gurandoru', indicating inferior suberization in cell walls of 'Life' periderm (Fig. 6). To evaluate the chemical components associated with the histological characteristics of 'Life' fruits, the lipid content of the net tissue was measured during netting stages (from stage III to V) (Fig. 7). The lipid content of net tissue in 'Life' fruits was often lower than that in net tissue of 'Andesu' and 'Gurandoru' fruits. Thus, insufficient development of suberin with wax depositions in 'Life' would result in higher moisture loss through the net tissue at least until stage IV. At stage
$\mathrm{V}$, however, the transpiration rate of the net tissue of 'Life' fruit was similar to that of 'Andesu' and 'Gurandoru' fruit (Fig. 4B), despite thinner suberized cell wall layers (Fig. 6) and lower lipid content (Fig. 7). This suggests that a threshold level of suberization might be required for the waterproofing ability.

POD activity is thought to be involved in the suberization of secondary cell walls of tomato (Sherf et al., 1993) and netted melon fruit (Biles et al., 2000; Keren-Keiserman et al., 2004b) because the last catalytic step in the synthesis of the lignin and the aromatic domain of suberin is the oxidation of cinnamyl

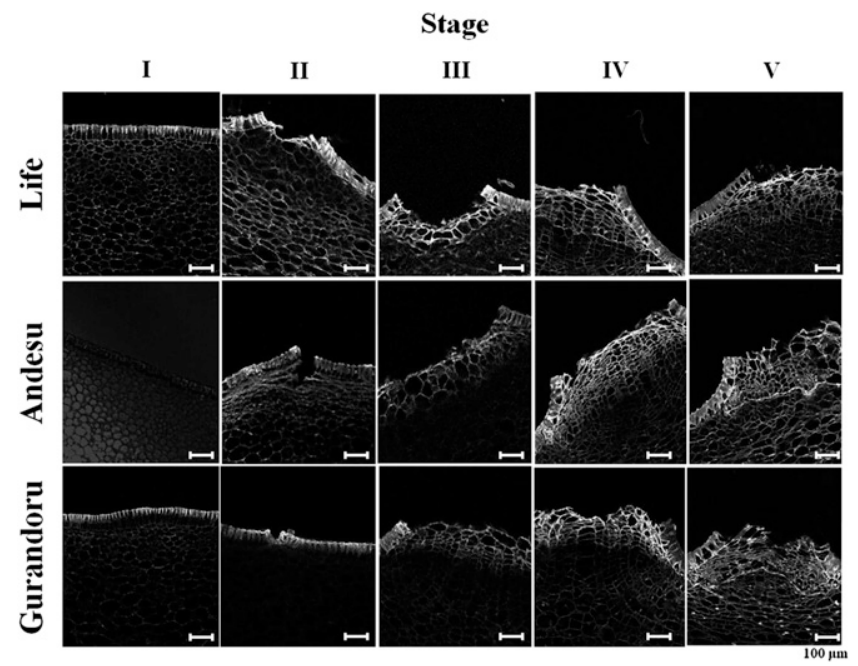

Fig. 6. Changes in the development of suberized cell walls in the cross sections of periderm tissues during fruit development. Distribution of suberized cell walls was visualized by autofluorescence.

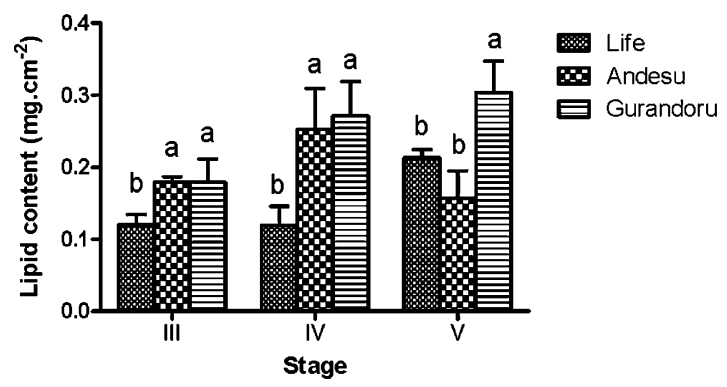

Fig. 7. Changes in lipid content of the net during fruit development. Different letters within columns indicate significant differences at $P \leq 0.05$ by Tukey's honestly significant difference test. Bars indicate mean \pm SD $(n=5)$.

alcohols catalyzed by POD (Quiroga et al., 2000). In 'Magnum-45' muskmelon fruit ( $C$. melo L. var. reticulatus), increase in total POD activity of exocarp corresponds to active net formation and the highest value is obtained when the fruit was fully netted (Biles et al., 2000). In our experiment, increase in POD activities of both 'Andesu' and 'Gurandoru' also corresponded well to the active net development but the value in 'Life' was low throughout fruit development (Fig. 8A), suggesting a correlation between lower POD activity and inferior periderm development.

POD activity is thought to be involved in the suberization of secondary cell walls of tomato (Sherf et al., 1993) and netted melon fruit (Keren-Keiserman et al., 2004b; Biles et al., 2000) because the final catalytic step in the synthesis of the lignin and the aromatic domain of suberin is the oxidation of cinnamyl alcohols catalyzed by POD (Quiroga et al., 2000). In 'Magnum-45' muskmelon fruit (C. melo L. var. reticulatus), an increase in the total POD activity of exocarp corresponds to active net formation, and the highest value is obtained when the fruit is fully netted (Biles et al., 2000). In our experiment, the increase in POD activities of both 'Andesu' and 'Gurandoru' also corresponded well to the active net development, but the value in 'Life' was low throughout fruit development (Fig. 8A), suggesting a correlation between lower POD activity and inferior periderm development.

POD activity associated with the suberization of periderm tissues in melon rind is often regulated by the ethylene level. That is, ethylene is required to activate POD for periderm initiation in the fissures of netted melon rind, but a constantly high ethylene level impedes cell division in the periderm, resulting in incomplete periderm tissue (Gerchikov et al., 2008; Keren-Keiserman et al., 2004b). In our experiment, however, changes in POD activity of 'Life' were unaffected by fluctuations in ethylene levels (Fig. 8B), as previously observed in the woundinduced suberization of potato tubers (Lulai and Suttle, 2004). Climacteric ethylene levels may not directly affect the development of healing periderm on naturally occurring fissures in netted melon fruit rind, because POD activity on the inner sides of the fissures can become high enough, and the periderm is initiated quickly in response to wounding,

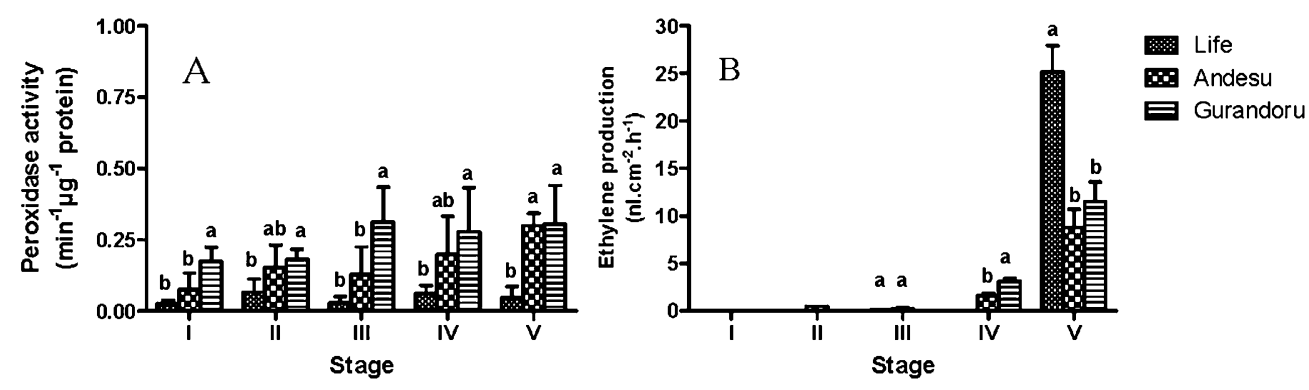

Fig. 8. Changes in (A) peroxidase activity and (B) ethylene production during fruit development. Different letters within columns indicate significant differences at $P \leq 0.05$ by Tukey's honestly significant difference test. Bars indicate mean $\pm \operatorname{SD}(n=5)$. 

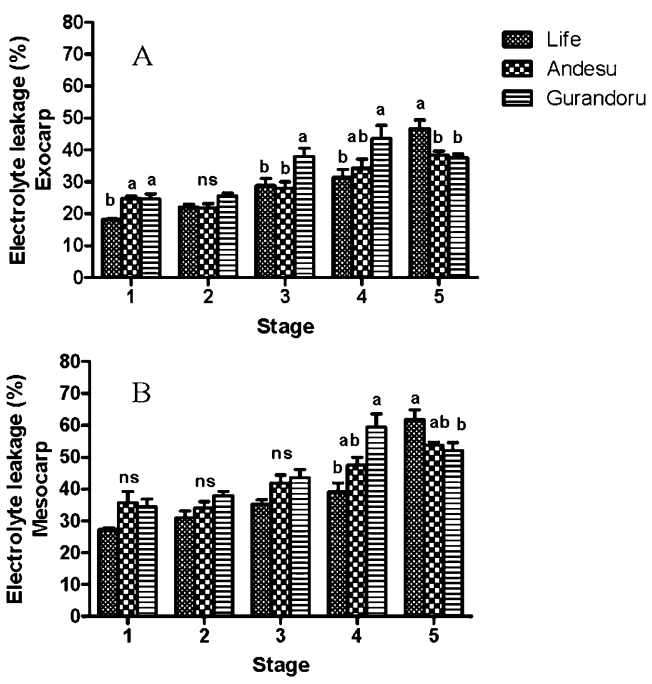

Fig. 9. Membrane permeability of (A) exocarp and (B) mesocarp during fruit development. Different letters within columns indicate significant differences at $P \leq 0.05$ by Tukey's honestly significant difference test. Bars indicate mean $\pm \mathrm{SD}(n=5)$.

even at the preclimacteric stage (KerenKeiserman et al., 2004b).

Skin netting is genetically determined in melons (Liu et al., 2004; Obando and Fernández-Trujillo, 2008). In netted melon fruits, at least five netting-associated QTLs have been mapped in different linkage groups (LG) of melons. Among them, one QTL is located in LG I, II, and III, respectively, and two QTLs are located in LG VIII, which shows an opposite effect (Obando and FernándezTrujillo, 2008). Another QTL is located in LG III, which promotes less skin netting than the control. Concerning ethylene production, two climacteric ethylene QTLs have been located in LG III and VI (Vegas et al., 2013). These results suggest that ethylene promoting netting will be involved in system I rather than autocatalytic one. Recently, FernándezTrujillo et al. (2013) also showed the importance of cracking in melons including susceptibility to net cracking that is genetically determined, and they also suggested that small bursts of ethylene production (increases of $\approx 1$ to $4 \mathrm{pmol} \cdot \mathrm{kg}^{-1} \cdot \mathrm{s}^{-1}$ of ethylene) could be a sign of healing in netted or stemend areas. Thus, the development of periderm tissues in netted melon fruit rind might be regulated by this transient increase in ethylene production rather than climacteric high ethylene production.

Clarifying the correlation between ethylene production and POD activity, which induces the suberization of periderm tissues in climacteric netted melon fruit, is difficult because the correlation can be easily masked by high ethylene evolution. It would be easier to use nonclimacteric melon cultivars or measure different POD isozymes during fruit development to clarify the correlation (Biles et al., 2000).

Electrolyte leakage values for the exocarp and mesocarp in 'Life' were often lowest until stage IV, but highest at stage V (Fig. 9), suggesting a correlation between high ethylene production and high membrane permeability
(Lester and Stein, 1993). When 'Life' fruit was harvested at the ripening stage, the membrane integrity of the hypodermal tissues decreased and cell wall polymers degraded during long-term storage, decreasing water conservation and accelerating fruit softening (Nishizawa et al., 2009). Therefore, the high climacteric ethylene evolution detected in 'Life' (Fig. 8B) likely affects fruit softening and deterioration associated with high membrane permeability in the hypodermal tissues.

In this study, we measured transpiration rates from the nets and cuticle layers separately using three netted melon cultivars belonging to the Reticulatus group with different ripening and netting characteristics. As the result, the transpiration rate from the nets at the fruit ripening stage did not differ significantly among cultivars, suggesting that the waterproofing ability of net tissues is not necessarily correlated with netting characteristics such as the embossment and width at the fruit ripening stage. Rather, the waterproofing ability of completed net tissues was as effective as that of cutinized cell walls even if the fissures were not fully healed by periderm. It is also known that lignification and suberization occur even in non-netted melon fruit, especially when the rind is wounded, but the development of healing periderm tissue is usually far less than that of netted melon cultivars (Gerchikov et al., 2008). Nevertheless, there is no evidence that moisture in non-netted melon fruit is mostly lost through these healed periderm tissues.

In conclusion, lignification and suberization will be limited in the periderm tissues of quickly growing netted melon fruit such as 'Life' probably because of its shorter developmental period, but the net tissue can retain a high waterproofing ability if suberized cell wall layers with wax depositions develop below the fissures at the fruit ripening stage.

\section{Literature Cited}

AOAC. 2000. Official methods of analysis. 17th Ed. Association of official analytical chemists, Gaithersburg, MD.

Argandoña, V.H., M. Chaman, L. Cardemil, O. Muñoz, G.E. Zúñiga, and L.J. Corcuera. 2001. Ethylene production and peroxidase activity in aphid-infested barley. J. Chem. Ecol. 27:5368.

Beaudry, R.M., N. Paz, C.C. Black, and S.J. Kays. 1987. Banana ripening: Implications of changes in internal ethylene and $\mathrm{CO}_{2}$ concentrations, pulp fructose 2,6-bisphosphate concentration, and activity of some glycolytic enzymes. Plant Physiol. 85:277-282.

Biles, C.L., B.D. Bruton, J.X. Zhang, and V. Russo. 2000. Characterization of muskmelon fruit peroxidases at different developmental stages. Biol. Plant. 43:373-379.

Bradford, M.M. 1976. A rapid and sensitive method for the quantitation of microgram quantities of protein utilizing the principle of protein-dye binding. Anal. Biochem. 72:248-254.

Cao, D.D., J. Hu, C.H. Gao, Y.J. Guan, S. Zhang, and J.F. Xiao. 2008. Chilling tolerance of maize (Zea mays L.) can be improved by seed soaking in putrescine. Seed Sci. Technol. 36:191-197.

Causse, M., V. Saliba-Colombani, L. Lecomte, P. Duffé, P. Rousselle, and M. Buret. 2002. QTL analysis of fruit quality in fresh market tomato: A few chromosome regions control the variation of sensory and instrumental traits. J. Expt. Bot. 53:2089-2098.

Chaïb, J., M.-F. Devaux, M.-G. Grotte, K. Robini, M. Causse, M. Lahaye, and I. Marty. 2007. Physiological relationships among physical, sensory, and morphological attributes of texture in tomato fruits. J. Expt. Bot. 58:1915-1925.

Chapman, N.H., J. Bonnet, L. Grivet, J. Lynn, N. Graham, R. Smith, G. Sun, P.G. Walley, M. Poole, M. Causse, G.J. King, C. Baxter, and G.B. Seymour. 2012. High-resolution mapping of a fruit firmness-related quantitative trait locus in tomato reveals epistatic interactions associated with a complex combinatorial locus. Plant Physiol. 159:1644-1657.

Combrink, N.J.J., G.A. Agenbag, P. Langenhoven, G. Jacobs, and E.M. Marais. 2001. Anatomica and compositional changes during fruit development of 'Galia' melons. S. Afr. J. Plant Soil. 18:7-14.

Dos-Santos, N., A. Jiménez-Araujo, R. RodríguezArcos, and J.P. Fernández-Trujillo. 2011. Cell wall polysaccharides of near-isogenic lines of melon (Cucumis melo L.) and their inbred parentals which show differential flesh firmness or physiological behavior. J. Agr. Food Chem. 59:7773-7784.

Fernández-Trujillo, J.P., G.E. Lester, N. DosSantos, J.A. Martínez, J. Esteva, J.L. Jifon, and P. Var. 2013. Pre- and postharvest muskmelon fruit cracking: Causes and potential remedies. HortTechnology 23:266-275.

Gerchikov, N., A. Keren-Keiserman, R. PerlTreves, and I. Ginzberg. 2008. Wounding of melon fruit as a model system to study rind netting. Sci. Hort. 117:115-122.

Keren-Keiserman, A., Z. Tanami, O. Shoseyov, and I. Ginzberg. 2004a. Peroxidase activity associated with suberization processes of the muskmelon (Cucumis melo) rind. Physiol. Plant. 121:141-148

Keren-Keiserman, A., Z. Tanami, O. Shoseyov, and I. Ginzberg. 2004b. Differing rind characteristics of developing fruits of smooth and netted melons (Cucumis melo). J. Hort. Sci. Biotechnol. 79:107-113. 
Knowles, N.R. and L.O. Knowles. 1989. Correlations between electrolyte leakage and degree of saturation of polar lipids from aged potato (Solanum tuberosum L.) tuber tissue. Ann. Bot. (Lond.) 63:331-338.

Lester, G.E. 1988. Comparisons of 'Honey Dew' and netted muskmelon fruit tissues in relation to storage life. HortScience 23:180-182.

Lester, G.E. and B.D. Bruton. 1986. Relationship of fruit waterless to netted muskmelon postharvest storage life. J. Amer. Soc. Hort. Sci. 111:727-731.

Lester, G.E. and E. Stein. 1993. Plasma membrane physicochemical changes during maturation and postharvest storage of muskmelon fruit. J. Amer. Soc. Hort. Sci. 118:223-227.

Liu, L., F. Kakihara, and M. Kato. 2004. Characterization of six varieties of Cucumis melo L. based on morphological and physiological characters, including shelf-life of fruit. Euphytica 135:305-313.

Lulai, E.C. and J.C. Suttle. 2004. The involvement of ethylene in wound-induced suberization of potato tuber (Solanum tuberosum L.): A critical assessment. Postharvest Biol. Technol. 34: 105-112.

Matas, A.J., N.E. Gapper, M.-Y. Chung, J.J. Giovannoni, and J.K.C. Rose. 2009. Biology and genetic engineering of fruit maturation for enhanced quality and shelf-life. Curr. Opin. Biotechnol. 20:197-203.

McClure, T.T. 1960. Chlorogenic acid accumulation and wound healing in sweet potato roots. Amer. J. Bot. 47:277-280.
Nishizawa, T., A. Ito, Y. Motomura, M. Ito, and M. Togashi. 2000. Changes in fruit quality as influenced by shading of netted melon plants (Cucumis melo L. 'Andesu' and 'Luster'). J. Jpn. Soc. Hort. Sci. 69:563-569.

Nishizawa, T., K. Okafuji, and H. Murayama. 2009. Storability and development of physiological disorder of netted melon 'Life' fruit as influenced by storage conditions. Acta Hort. 837:147-154.

Nishizawa, T., A. Tamura, S. Mitsuzuka, T. Aikawa, M. Togashi, and Y. Motomura. 2002. Water-soaked symptom of 'Andesu' netted melon fruit is not developed under anaerobic nitrogen atmospheres during ripening. Plant Growth Regulat. 38:7-14.

Obando, J. and J.P. Fernández-Trujillo. 2008. Identification of melon fruit quality quantitative trait loci using near-isogenic lines. J. Amer. Soc. Hort. Sci. 133:139-151.

Quiroga, M., C. Guerrero, M.A. Botella, A. Barcelo, and I. Amaya. 2000. A tomato peroxidase involved in the synthesis of lignin and suberin. Plant Physiol. 122:1119-1128.

Riederer, M. and L. Schreiber. 2001. Protecting against water loss: Analysis of the barrier properties of plant cuticles. J. Expt. Bot. 52:2023-2032.

Rose, J.K.C., K.A. Hadfield, J.M. Labavitch, and A.B. Bennett. 1998. Temporal sequence of cell wall disassembly in rapidly ripening melon fruit. Plant Physiol. 117:345-361.

Saladié, M., A.J. Matas, T. Issacson, M.A. Jenks, S.M. Goodwin, K.J. Niklas, R. Xiaolin, J.M. Labavich, K.A. Shackel, A.R. Fernie, A.
Lytovchenko, M.A. O’Neill, C.B. Watkins, and J.K.C. Rose. 2007. A reevaluation of the key factors that influence tomato fruit softening and integrity. Plant Physiol. 144:1012-1028.

Schreiber, L. 2010. Transport barrier made of cutin, suberin and associated waxes. Trends Plant Sci. 15:546-553.

Schreiber, L., R. Franke, and K. Hartmann. 2005. Wax and suberin development of native and wound periderm of potato (Solanum tuberosum L.) and its relation to peridermal transpiration. Planta 220:520-530.

Seko, T. 2004. Melon. Gendai-nougyo. 2004(2): 140-143 (In Japanese).

Serra, O., C. Hohn, R. Franke, S. Prat, M. Molinas, and M. Figueras. 2010. A feruloyl transferase involved in the biosynthesis of suberin and suberin-associated wax is required for maturation and sealing properties of potato periderm. Plant J. 62:277-290.

Sherf, B.A., A.M. Bajar, and E. Kolattukudy. 1993. Abolition of an inducible highly anionic peroxidase activity in transgenic tomato. Plant Physiol. 101:201-208.

Suzuki, E. and T. Nonaka. 2004. Mechanism of net development, p. 95-98. In: Melon. Nobunkyo, Tokyo (In Japanese).

Vegas, J., J. Garcia-Mas, and A.J. Monforte. 2013. Interaction between QTLs induces an advance in ethylene biosynthesis during melon fruit ripening. Theor. Appl. Genet. 126:1531-1544.

Webster, B.D. and M.E. Craig. 1976. Net morphogenesis and characteristics of the surface of muskmelon fruit. J. Amer. Soc. Hort. Sci. 101:412-441. 